$$
\begin{gathered}
\text { 그림책읽기 후속활동이 영아의 언어 및 } \\
\text { 사회 - 정서발달에 미치는 영향 } \\
\text { 이 화 진·서 현 아* } \\
\text { 해운대초등어린이집·경성대학교 유아교육과 * }
\end{gathered}
$$

\title{
The Influence of Follow-up Activities after Reading Picture Books on Language and Socio-emotional Development of Infants
}

\author{
Lee, Wha Jin · Seo, Hyun $\mathrm{Ah}^{*}$ \\ Haeundae Elementary Nursury School \\ Dept. of Early Childhood Education, Kyungsung University, Busan, Korea*
}

\begin{abstract}
The purpose of this study was to find out how follow-up activities of reading picture books influenced infants' language and socio-emotional development. Subjects of this study were 27 2-year-old infants at public day care centers in Busan. After implementing follow-up activities of reading picture books for 8 weeks, this study tried to investigate changes in infants' language and socio-emotional development. Results of this study are as follows. First, follow-up activities of reading pictures have brought positive impacts on infants' language ability. Results indicate a positive influence on infants' expressive and acceptive language ability. Second, follow up activities have also enhanced infants' socio-emotional development. Sepcifically, they have been effective in improving infants' low-level socio-emotional development such as 'internal control', 'peer interaction', and 'achievement motivation'. It is expected that the follow-up activities developed by this research would help to enhance infants' language development and socio-emotional development.
\end{abstract}

Key words: follow-up activities after reading picture books, language development. socio-emotional development

I. 서론

1. 연구의 필요성 및 목적

영아기는 인간의 발달단계에서 대부분의 발달
이 결정되는 중요한 시기이다. 따라서 영아기 교 육은 다른 어떤 연령의 교육보다 신중한 접근이 요구되는 어려운 과제라 하겠다. 이에 장영희 (2005)는 영아기에 형성된 사회·정서발달은 이

접수일: 2011년 7월 31일 심사일: 2011년 8월 15일 채택일: 2011년 9월 19일

Corresponding Author: Seo, Hyun Ah Tel: 82-10-3206-3878

e-mail: shyna@ks.ac.kr 
후의 발달단계에 밀접한 영향을 미치므로 영아기 에 어떠한 사회·정서를 경험하느냐의 문제는 매 우 중요하다고 하였고, 조성원(2008)은 영아는 24 개월에서 36 개월에 이르면 어휘의 확장은 물론 문법적인 형태소를 사용하고 성인이 사용하는 언 어와 유사한 언어체계를 습득하게 된다고 하였다.

영아들의 발달에 영향을 미치는 사람, 사물, 사건 중에서 영아들이 가장 쉽게 경험하는 환경 이자 교육 매체인 그림책은 영아의 언어발달 뿐 아니라 사회·정서발달 및 인지발달 등 전반적인 영역의 발달을 돕기 위해 적극적으로 활용되는 매체이다(이상금 1998). 따라서 영아기에 그림책 을 보는 것은 단순히 글자나 지식을 얻기 위함이 아니라 그림책을 통해 숨은 감성을 끌어내고 앞 으로의 독서생활을 위한 긍정적 경험을 획득하는 것을 궁극적 목적으로 해야 한다. 즉, 영아가 그 림책을 통해 즐겁고 재미있는 발견을 하도록 하 여 자신을 둘러싸고 있는 세계를 새롭게 만나게 하며 독서에 대한 취향과 태도를 형성하도록 하 는 것이다. 따라서 가능하면 영아들이 그림책을 통해 세상에 대한 지식과 지혜를 얻고, 아름다운 상상의 세계가 주는 즐거움과 기쁨을 많이 경험 할 수 있도록 하며, 책은 재미있는 것이라는 인 상을 심어주는 것이 필요하다(마쯔이 다다시 1990).

한편 영아기의 언어 발달은 말 그대로 폭발적 이다. '엄마', '맘마' 등의 한마디로 시작해 초등 학교에 입학할 무렵에는 약 2,500 개의 기본적 어 휘를 사용할 수 있고 이해할 수 있는 어휘는 이 보다 훨씬 많다. 세 살쯤 되면 제법 대화가 가능 하며 아이는 숼새없이 조잘거린다. 또한 영아는 2 세에서 3 세 사이가 되면 줄거리가 있는 그림책 을 좋아하기 시작한다. 자기와 같은 경험을 하고 있는 그림책속의 세계로 빨려들기 마련인데, 이 때부터 그림책이 재미있어서 끝까지 조용히 귀를 기울이고 들을 수 있게 된다. 오진희(2000)는 영 아의 발달에 적합한 그림책읽기활동은 언어능력 의 증진 특히 읽기 능력 및 어휘력의 학습, 문해 능력의 향상, 추론 능력, 이해력, 조망능력, 상상 력, 그리고 여러 정서적인 발달을 증진시킬 수 있는 효과적인 방법 중의 하나이며 영아의 심미 적 반응을 경험하게 하는 중요한 활동이라고 하
였다. 그림책읽기 활동은 영아의 언어 발달 뿐 아니라 사회 - 정서발달에도 영향을 미친다고 하 는데, Bridges(1930)에 의하면 영아기 동안 대부분 의 정서가 분화 - 발달하여 대체로 2 세가 끝날 무 렵까지는 성인에게서 볼 수 있는 거의 모든 정서 가 나타나며, 나이가 들수록 정서적인 감수성이 예민해지고 표현방식이 세련되어 가지만, 기본이 되는 정서의 발현은 영아기에 완성된다고 한다. 최석란(2007)은 생후 3년 이내에 영아가 경험하 는 적절한 자극과 교육들은 영아의 사회·정서발 달에 긍정적인 영향을 가져오고, 기질적 특성, 영 아에 대한 무관심, 스트레스, 가난과 같은 부정적 인 자극은 영아의 사회-정서발달을 저해한다고 한다. 이와 같이 인간의 발달에 있어서 영아기의 사회·정서발달은 매우 중요하기 때문에 영아기 에 충분히 사회 - 정서에 관한 교육이 이루어져야 하는데, 이러한 영아들의 사회- 정서발달을 도울 수 있는 가장 좋은 교수 매체로 그림책을 들 수 있다.

Mayer와 Salovey(1997)는 그림책을 통한 정서 학습은 교육체계를 통하여 지속되어질 수 있으며 보다 효율적인 학습을 할 수 있다고 주장하였다. 이와 같이 영아에게 적절한 사회-정서그림책을 소개하고 읽어주는 활동은 영아의 정서 및 심미 적 반응을 경험하게 하는 중요한 활동이 될 것이다.

최근에는 영아기의 중요성이나 맞벌이 핵가족 화에 따른 사회적 상호작용의 필요성 등 여러 가 지 요인이 복합적으로 작용하면서 영아교육에 대 한 요구도는 더 높아지고 있다. 이에 영아 보육 기관이 증가해 감에 따라 영아기의 보육 경험과 언어 발달과의 관계, 사회·정서발달과의 관계 등 영아의 발달을 주제로 한 연구들이 많이 이루 어지고 있다.

영아를 대상으로 한 보육기관에서 가장 많이 하는 활동 중의 하나인 그림책 읽어주기가 책에 제시된 글자만 읽고 활동을 마치는 것이 아니라 책을 매개로 다양하고 질 높은 언어적 상호작용 을 이끌 수 있고, 영아들이 그림책을 통해 또래 들과 사회적 놀이를 하며, 정서적 안정감을 경험 할 수 있는 구체적인 교수방법이 요구된다. 또한, 보육기관에서는 한 교사가 다수의 영아들을 대상 
으로 하기 때문에 그림책을 활용하여 집단적으로 할 수 있는 다양한 언어프로그램 및 사회·정서 발달프로그램이 필요하다고 본다. 한편 영아를 위한 그림책관련활동은 그림책읽기에 제한적이 었으며, 그림책읽기가 언어발달에 미치는 영향을 살펴 본 것이 대부분이라 하겠다. 실제로 어린이 집에서 그림책읽기 후속활동 프로그램을 진행하 고 있는 보육기관도 많이 늘어났으나, 영아들의 발달적 특성에 맞추어 온 몸의 감각기관, 신체를 활용하여 활동하는 다양한 프로그램에 대한 연구 는 부족한 실정이라 할 수 있다.

영아들에게 그림책을 그저 읽어 주기만 한다 면 영아들은 수동적인 청취자가 될 수밖에 없으 므로 책을 읽는 것만큼 중요한 것이 그림책을 읽 는 동안 성인 -영아의 상호작용을 활발히 하는 것이다. 즉, 책을 읽는 중이나 읽고 난 후에 책과 관련된 다양한 활동을 한다면 영아는 자신의 개 인적인 경험이나 여러 가지 현상, 사건 등을 쉽 게 연결시키고, 상상력과 창의성을 발휘할 수 있 게 될 것이다. 따라서 영아들의 그림책 읽기 활 동은 교사와 영아, 영아와 영아들 간의 긴밀한 상호작용이 이루어지는 가운데 함께 읽고, 이야 기하고, 영아의 생활과 발달에 적합한 다양한 활 동들이 계획되어져야 할 것이다.

발달적으로 보면 영아기는 언어나 사회-정서 가 가장 발달하는 시기이므로 그림책관련 후속활 동의 효과가 기대된다고 할 수 있겠다. 특히, 만 2세 영아는 Piaget의 감각운동기 말기에서 전조작 기 초기에 해당되는 시기로 활동적이고 독립심이 강하며 자신의 감각기관을 통해 주변 세계를 탐 색하는 것을 좋아한다. 이처럼 영아는 자신이 탐 색한 환경을 감각적으로 경험하면서 여러 가지 사물을 사용해 보고 조작하면서 사물에 대한 이 해를 높이며 언어를 구사한다. 뿐만 아니라 이렇 게 획득한 감각운동적 경험들을 놀이로 확장하면 서 물리적 지식, 논리 수학적 지식, 사회적 지식 등을 구성해 나간다. 이러한 영아들의 발달특성 을 고려해 볼 때 단순한 그림책을 읽어주는 활동 을 넘어 교사와 영아가 그림책을 읽은 후 온 몸 의 감각을 활용할 수 있는 후속활동이 필요하다 하겠다. 그림책읽기 후속활동은 영아의 발달과
생활을 토대로 대소근육을 이용한 놀이, 언어활 동, 창의적 놀이(음률, 조형, 극놀이) 상징놀이, 탐색활동 등 다양한 활동이 있다. 이런 활동 등을 통해서 언어를 활발하게 구사하게 되며 다양한 느낌을 받아 자신의 감정이나 정서를 잘 표현할 수 있고 타인의 정서를 이해할 수 있을 것이다.

따라서 본 연구에서는 감각을 통해 세상을 인 식하는 영아의 특성과 영아기의 사회·정서발달 의 중요성을 고려하여 교사와 영아가 그림책읽기 후 발달에 적합한 후속활동을 구성하고, 이를 실 행한 후 그림책읽기 후속활동이 영아의 언어발달 및 사회·정서발달에 미치는 영향을 알아보고자 한다.

\section{2. 연구문제}

1. 그림책읽기 후속활동이 영아의 언어발달에 미치는 영향은 어떠한가?

2. 그림책읽기 후속활동이 영아의 사회·정서 발달에 미치는 영향은 어떠한가?

\section{II. 연구방법}

\section{1. 연구대상}

본 연구는 $\mathrm{P}$ 시의 $\mathrm{H}$ 어린이집과 $\mathrm{R}$ 어린이집 만 2 세 영아 27 명을 대상으로 하였다. $\mathrm{H}$ 어린이집과 $\mathrm{R}$ 어린이집은 표준보육과정을 실시하고 있었으며, 두 기관 모두 평가인증을 통과하였다. 27명의 영 아 중 실험집단은 $\mathrm{H}$ 어린이집의 만 2세반 영아 14 명이었으며, 비교집단은 R어린이집 만2세반 영 아 13 명이었다. 선정된 두 기관의 영아의 평균 연령은 동질한 집단으로 구성되었다. 대상 연령 별 분포는 다음 표 1 과 같다.

표 1. 영아의 평균 연령 비교

$(\mathrm{N}=27)$

\begin{tabular}{|c|c|c|c|c|c|}
\hline \multirow{2}{*}{ 집단 } & \multirow{2}{*}{$\mathrm{n}$} & \multicolumn{2}{|c|}{ 성별 } & \multirow{2}{*}{$\begin{array}{l}\text { 평균 } \\
\text { 월령 }\end{array}$} & \multirow{2}{*}{$t$} \\
\hline & & 남 & 여 & & \\
\hline 비교집단 & 13 & 5 & 8 & 37.54 & \multirow{2}{*}{-1.51} \\
\hline 실험집단 & 14 & 6 & 8 & 39.21 & \\
\hline 전체 & 27 & 11 & 16 & 38.41 & \\
\hline
\end{tabular}




\section{2. 검사도구}

\section{1) 본 연구에 사용된 그림책}

본 연구에 사용할 영아의 언어 및 사회·정서 발달에 적합한 그림책을 선정하기 위하여 김세희 (2000)와 김현희 - 박상희(1999)의 이론적 근거와 유아에게 적절한 그림책(노영희 - 이경우 - 이차숙 - 장영희 - 현은자 1997)에서 추천하는 그림책을 기준으로 영아의 정서 및 언어발달에 관한 주제 를 포함하고 있는 동화 총 40 편을 1 차적으로 선정 하였다. 1 차 선정된 도서를 그림책읽기 후속활동 을 유아교육 전문가 2 인에게 검증받은 후 2 차적 으로 만 2세의 사회-정서 및 언어관련 그림책 30 편을 선정하였다. 2 차 선정된 도서를 대학원에 서 유아교육을 전공한 현직 영아반 교사 3 명과 협의하여 표준보육과정에 적합한 8 편의 도서를 최종 선정하였다.

본 연구에 사용한 그림책은 표 2 와 같다.

\section{2) 그림책읽기 후속 활동안}

본 연구에서 사용된 그림책읽기 후속활동은
영아의 대소근육 및 감각을 이용한 놀이 언어활 동, 창의적 놀이(음률, 조형, 극놀이) 상징놀이, 탐색활동 등 다양한 활동으로 총 24회기를 구성 하였다. 본 연구의 그림책읽기 후속활동은 어린 이집 원장 3 인과 유아교육 전문가 1 인, 유아교육 을 전공한 석사학위 이상을 자격을 소유한 영아 교사 2 인에게 타당도를 검증받았다. 그림책읽기 후속활동의 구체적 내용은 표 3 과 같다.

\section{3) 만2세 영아 언어발달 도구}

그림책읽기 후속활동이 영아의 언어능력 즉, 표현언어와 수용언어에 미치는 영향을 검증하기 위하여 사용된 표준화된 검사지는 영유아언어발 달검사(SELSI: Sequenced Language Scale for Infants, 김영태 2003)이다.

영유아 언어발달 검사는 생후 5 개월부터 36 개 월 사이의 정상아동 및 언어발달 장애를 나타낼 가능성이 있는 아동의 언어능력을 평가하기 위한 검사 도구로 영아의 발달을 잘 아는 부모나 영아 의 주양육자(보육기관 교사)를 통하여 면담이나 직접적인 관찰로 이루어지며 검사 결과는 영아의

표 2. 본 연구에 사용된 그림책 목록

\begin{tabular}{|c|c|c|c|c|}
\hline 순 & 도서명 & 저자명 & 출판사 & 내용 \\
\hline 1 & 파도야 놀자 & 이수지 & 비룡소 & $\begin{array}{l}\text { 어느 화창한 여름날 엄마와 함께 한적한 바닷가에 } \\
\text { 놀러온 소녀의 특별한 이야기 }\end{array}$ \\
\hline 2 & 아빠랑 목욕해요 & $\begin{array}{l}\text { 와타니베 } \\
\text { 시게오 }\end{array}$ & 북뱅크 & $\begin{array}{l}\text { 흙투성이가 되어 집으로 돌아온 아기곰과 아빠곰의 } \\
\text { 즐거운 목욕놀이 이야기 }\end{array}$ \\
\hline 3 & 사과가 쿵! & $\begin{array}{l}\text { 다다 } \\
\text { 히로시 }\end{array}$ & 보림 & $\begin{array}{l}\text { 숲 속 동물들이 펼치는 즐겁고 신나는 사과잔치 } \\
\text { 이야기 }\end{array}$ \\
\hline 4 & $\begin{array}{l}\text { 누가 내 머리에 } \\
\text { 똥 쌌어? }\end{array}$ & $\begin{array}{c}\text { 베르너 } \\
\text { 홀츠바르트 }\end{array}$ & 사계절 & $\begin{array}{l}\text { 자신의 머리에 똥을 싼 누군가를 찾아 떠나는 이야기. } \\
\text { 철퍼덕! 쿠당탕탕! 쫘르륵! 등의 의성어와 의태어가 } \\
\text { 재미있다. }\end{array}$ \\
\hline 5 & 유모차 나들이 & 미셸 게 & 비룡소 & $\begin{array}{l}\text { 유모차를 통해 남을 보살필 줄알게 되는 아이의 } \\
\text { 모습을 보여주는 이야기 }\end{array}$ \\
\hline 6 & 나랑 같이 놀자 & $\begin{array}{l}\text { 마리홀 } \\
\text { 에츠 }\end{array}$ & 시공 주니어 & $\begin{array}{l}\text { 혼자서 들판에 놀러 나왔다가 동물친구들과 함께 놀게 } \\
\text { 되기까지의 과정을 수수하게 그린 이야기 }\end{array}$ \\
\hline 7 & 우리는 친구 & $\begin{array}{l}\text { 앤서니 } \\
\text { 브라운 }\end{array}$ & 웅진 주니어 & $\begin{array}{l}\text { 모습이나 크기로 봐서는 어울릴것처럼 보이지 않는 } \\
\text { 고릴라와 고양이의 우정을 그린 이야기 }\end{array}$ \\
\hline 8 & 강아지똥 & 권정생 & 길벗 어린이집 & $\begin{array}{l}\text { 아무도 거들떠 보지 않는 세상에서 가장 버림 받는 } \\
\text { 존재인 '강아지똥'도 알고 보면 정말 소중한 존재라는 } \\
\text { 사실을 알려주는 이야기 }\end{array}$ \\
\hline
\end{tabular}


표 3. 그림책읽기 후속활동 차시별 주제 및 활동

\begin{tabular}{|c|c|c|c|c|}
\hline 회기 & $\begin{array}{l}\text { 그림책 } \\
\text { 제목 }\end{array}$ & $\begin{array}{c}\text { 활동 } \\
\text { (활동명) }\end{array}$ & 활동목표 & 활동내용 \\
\hline 1 & $\begin{array}{l}\text { 파도야 } \\
\text { 놀자 }\end{array}$ & $\begin{array}{c}\text { 언어활동 } \\
\text { (보고 말하기) }\end{array}$ & $\begin{array}{l}\text { 동화감상 } \\
\text { 자신의 감정, 정서표현 }\end{array}$ & 그림책을 보고 회상해 본다. \\
\hline 2 & $\begin{array}{l}\text { 파도야 } \\
\text { 놀자 }\end{array}$ & $\begin{array}{l}\text { 대소근육활동 } \\
\text { (파도타면서 } \\
\text { 물고기 잡기) }\end{array}$ & $\begin{array}{l}\text { 신체활동에 } \\
\text { 즐겁게 참여 } \\
\text { 또래들과 긍정적 상호작용 }\end{array}$ & $\begin{array}{l}\text { 영아들이 흥미 있어 하는 파라슈트를 } \\
\text { 이용해 파도 타는 흥내를 내어 보며 } \\
\text { 같이 움직여 보는 활동이다. }\end{array}$ \\
\hline 3 & $\begin{array}{l}\text { 파도야 } \\
\text { 놀자 }\end{array}$ & $\begin{array}{l}\text { 감각적 탐색활동 } \\
\text { (출렁출렁 미끌미끌) }\end{array}$ & $\begin{array}{l}\text { 오감각을 사용하여 활동에 참여 } \\
\text { 자신의 정서를 말로 표현 }\end{array}$ & $\begin{array}{l}\text { 풀장 안에서 오감각을 이용하여 풀을 } \\
\text { 탐색해 보고 놀이를 즐긴다. }\end{array}$ \\
\hline 4 & $\begin{array}{l}\text { 아빠랑 } \\
\text { 목욕해요 }\end{array}$ & $\begin{array}{c}\text { 언어 활동 } \\
\text { (듣고 말하기) }\end{array}$ & 동화 듣고 말로 표현해 본다. & 동화를 듣고 내용에 대해 말해 본다. \\
\hline 5 & $\begin{array}{l}\text { 아빠랑 } \\
\text { 목욕해요 }\end{array}$ & $\begin{array}{l}\text { 감각적 탐색활동 } \\
\text { (비누거품놀이) }\end{array}$ & $\begin{array}{l}\text { 오감각을 사용해 탐색한다. } \\
\text { 물놀이의즐거움을 안다 }\end{array}$ & $\begin{array}{l}\text { 비누, 거품기 등 다양한 소품을 이용해 } \\
\text { 물속에서 비누거품놀이 활동을 한다. }\end{array}$ \\
\hline 6 & $\begin{array}{l}\text { 아빠랑 } \\
\text { 목욕해요 }\end{array}$ & $\begin{array}{c}\text { 창의적 활동 } \\
\text { (페트병 분수놀이) }\end{array}$ & $\begin{array}{l}\text { 또래들과 긍정적 상호작용한다. } \\
\text { 재활용품 이용해 놀이를 해 본다. }\end{array}$ & $\begin{array}{l}\text { 재활용품을 이용해 물속에서 } \\
\text { 분수놀이를 즐긴다. }\end{array}$ \\
\hline 7 & 사과가 쿵 & $\begin{array}{c}\text { 언어활동 } \\
\text { (듣고 말하기) }\end{array}$ & $\begin{array}{l}\text { 다양한 소리를 들어본다. } \\
\text { 동화장면을 말로 표현한다. }\end{array}$ & $\begin{array}{l}\text { 그림책을 감상한 후 의성어를 흥내내어 } \\
\text { 본다. }\end{array}$ \\
\hline 8 & 사과가 쿵 & $\begin{array}{c}\text { 언어활동 } \\
\text { (보고 말하기) }\end{array}$ & $\begin{array}{l}\text { 동화를 통해 자신의 감정, 정서 } \\
\text { 표현한다. }\end{array}$ & $\begin{array}{l}\mathrm{OHP} \text { 를 활용해 그림자극을 감상해 } \\
\text { 본다. }\end{array}$ \\
\hline 9 & 사과가 쿵 & $\begin{array}{l}\text { 창의적활동 } \\
\text { 상징(동극) }\end{array}$ & $\begin{array}{l}\text { 동극을 통해 언어 또는 신체로 } \\
\text { 표현해 본다. }\end{array}$ & $\begin{array}{l}\text { 등장하는 동물들의 신체표현 또는 } \\
\text { 동극을 꾸며 본다. }\end{array}$ \\
\hline 10 & $\begin{array}{l}\text { 누가 내 } \\
\text { 머리에 } \\
\text { 똥쌌어? }\end{array}$ & $\begin{array}{l}\text { 언어적 활동 } \\
\text { (듣고 말하기) }\end{array}$ & 새로운 어휘의 경험을 해 본다. & $\begin{array}{l}\text { 그림책을 들려주고 등장하는 } \\
\text { 동물이름을 말해 본다. }\end{array}$ \\
\hline 11 & $\begin{array}{l}\text { 누가 내 } \\
\text { 머리에 } \\
\text { 똥쌌어? }\end{array}$ & $\begin{array}{l}\text { 창의적 활동(조형) } \\
\text { 동물들의 똥 } \\
\text { 만들기 }\end{array}$ & $\begin{array}{l}\text { 여러 가지재료(색점토, 모래 } \\
\text { 등)사용해 창의적으로 표현한다. }\end{array}$ & $\begin{array}{l}\text { 지점토, 색점토를 이용해 질감을 } \\
\text { 느껴보고 동물들의 똥을 만들어본다. } \\
\text { (자신들의 정서 인식하고 표현하기) }\end{array}$ \\
\hline 12 & $\begin{array}{l}\text { 누가 내 } \\
\text { 머리에 } \\
\text { 똥쌌어? }\end{array}$ & $\begin{array}{l}\text { 감각적 탐색활동 } \\
\text { (모래로 똥만들기) }\end{array}$ & $\begin{array}{l}\text { 또래들과 긍정적으로 } \\
\text { 상호작용하면서 놀이한다. }\end{array}$ & $\begin{array}{l}\text { 모래를 만져보고 여러 가지 도구를 } \\
\text { 활용해 놀이를 해보고 물을 사용해 } \\
\text { 동물의 똥도 만들어 본다. }\end{array}$ \\
\hline 13 & $\begin{array}{l}\text { 유모차 } \\
\text { 나들이 }\end{array}$ & $\begin{array}{l}\text { 언어적 활동 } \\
\text { (듣고 말하기) }\end{array}$ & $\begin{array}{l}\text { 그림책 속 반복되는 말 } \\
\text { 흥내내보기 }\end{array}$ & 그림책의 내용을 회상하면서 듣는다. \\
\hline 14 & $\begin{array}{l}\text { 유모차 } \\
\text { 나들이 }\end{array}$ & $\begin{array}{l}\text { 대소근육활동 } \\
\text { (유모차태우기 } \\
\text { 게임) }\end{array}$ & $\begin{array}{l}\text { 또래들과 규칙을 정해 } \\
\text { 게임에 참여해 본다. }\end{array}$ & $\begin{array}{l}\text { 아기 유모차를 이용해 인형을 태우고 } \\
\text { 돌아오기 게임을 친구와 해 본다, }\end{array}$ \\
\hline 15 & $\begin{array}{l}\text { 유모차 } \\
\text { 나들이 }\end{array}$ & $\begin{array}{l}\text { 창의적활동-상징 } \\
\text { (동극놀이) }\end{array}$ & $\begin{array}{l}\text { 동극을 통해 자신의 정서 } \\
\text { 표현한다. } \\
\text { 돌봄에 대해 안다. }\end{array}$ & $\begin{array}{l}\text { 바깥놀이터에서 그림책의 내용처럼 } \\
\text { 직접 동극을 해 본다. }\end{array}$ \\
\hline 16 & $\begin{array}{l}\text { 나랑 같이 } \\
\text { 놀자 }\end{array}$ & $\begin{array}{l}\text { 언어적 활동 } \\
\text { (듣고 말하기) }\end{array}$ & $\begin{array}{l}\text { 동화감상하며 내용에 대해 } \\
\text { 이야기나눈다. }\end{array}$ & 내용을 회상하면서 동화를 듣는다. \\
\hline 17 & $\begin{array}{l}\text { 나랑 같이 } \\
\text { 놀자 }\end{array}$ & $\begin{array}{l}\text { 창의적 활동-상징 } \\
\text { (동물흥내내기) }\end{array}$ & $\begin{array}{l}\text { 동물흉내를 내어 본다. } \\
\text { 다른 사람의 감정에 관심을 } \\
\text { 가진다. }\end{array}$ & $\begin{array}{l}\text { 그림책에 나오는 동물을 그림판을 } \\
\text { 제작하여 영아들이 동물이 되어 표정을 } \\
\text { 지어보고 동물흥내를 내어 본다. }\end{array}$ \\
\hline
\end{tabular}


표 3. 계속

\begin{tabular}{|c|c|c|c|c|}
\hline 회기 & $\begin{array}{l}\text { 그림책 } \\
\text { 제목 }\end{array}$ & $\begin{array}{c}\text { 활동 } \\
\text { (활동명) }\end{array}$ & 활동목표 & 활동내용 \\
\hline 18 & $\begin{array}{l}\text { 나랑 같이 } \\
\text { 놀자 }\end{array}$ & $\begin{array}{l}\text { 창의적 활동-상징 } \\
\text { (동극놀이) }\end{array}$ & $\begin{array}{l}\text { 또래들과 동극을 하며 } \\
\text { 긍정적으로 상호작용 한다. }\end{array}$ & $\begin{array}{l}\text { 영아들이 동물머리띠를 쓰고 풀밭에서 } \\
\text { 동극활동을 한다. }\end{array}$ \\
\hline 19 & $\begin{array}{l}\text { 우리는 } \\
\text { 친구 }\end{array}$ & $\begin{array}{l}\text { 언어적 활동 } \\
\text { (듣고 말하기) }\end{array}$ & $\begin{array}{l}\text { 동화의 내용을 회상하며 } \\
\text { 이야기를 구성한다. } \\
\text { 다양한 감정에 대해 느껴본다. }\end{array}$ & 그림책의 내용을 회상하면서 듣는다. \\
\hline 20 & $\begin{array}{l}\text { 우리는 } \\
\text { 친구 }\end{array}$ & $\begin{array}{l}\text { 창의적 활동-조형 } \\
\text { (친구얼굴 꾸미기) }\end{array}$ & $\begin{array}{l}\text { 친구들에게 관심 갖기 즐겁게 } \\
\text { 활동에 참여한다. }\end{array}$ & $\begin{array}{l}\text { 재활용품을 이용해 친구얼굴을 } \\
\text { 꾸며본다. }\end{array}$ \\
\hline 21 & $\begin{array}{l}\text { 우리는 } \\
\text { 친구 }\end{array}$ & $\begin{array}{l}\text { 창의적 활동-음률 } \\
\text { (친구랑 춤추기) }\end{array}$ & $\begin{array}{l}\text { 타인과 긍정적으로 } \\
\text { 상호작용한다. }\end{array}$ & $\begin{array}{l}\text { 짝과 함께 음악에 맞추어 즐겁게 춤을 } \\
\text { 추어 본다. }\end{array}$ \\
\hline 22 & 강아지똥 & $\begin{array}{c}\text { 언어활동 } \\
\text { (듣고 말하기) }\end{array}$ & $\begin{array}{l}\text { 동화내용 회상한 후 이야기 } \\
\text { 구성해 보기 타인의 정서를 } \\
\text { 인식한다. }\end{array}$ & 그림책의 내용을 회상하면서 듣는다. \\
\hline 23 & 강아지똥 & $\begin{array}{l}\text { 자연 탐색활동 } \\
\text { (새둥지를 } \\
\text { 만들어요) }\end{array}$ & $\begin{array}{l}\text { 자연에서 탐색활동을 즐긴다. } \\
\text { 타인과 긍정적 상호작용한다. }\end{array}$ & $\begin{array}{l}\text { 직접 숲에 가서 자연물을 이용해 } \\
\text { 친구들과 새둥지를 만들어 본다. }\end{array}$ \\
\hline 24 & 강아지똥 & $\begin{array}{c}\text { 자연 탐색활동 } \\
\text { 대소근육활동 } \\
\text { (무궁화 꽃이 } \\
\text { 피었습니다) }\end{array}$ & $\begin{array}{l}\text { 자연의 고마움을 표현해 본다. } \\
\text { 자신의 정서와 타인의 정서를 } \\
\text { 느낀다. }\end{array}$ & $\begin{array}{l}\text { 솦에 가서 나무의 질감을 느껴보고 } \\
\text { 안아봄으로써 나무를 사랑하는 마음을 } \\
\text { 가지도록 놀이를 통해 전개해 본다. }\end{array}$ \\
\hline
\end{tabular}

언어발달 중에서도 특히, 표현 언어 및 수용 언 어 발달을 분석할 수 있다.

검사지는 표현 언어와 수용 언어로 나누어져 있으며 월령을 24 27개월, 28 31개월, 32 35개월 로 구분하였으며, 김영태 등(2003)은 만 2세 영아 는 기본적인 어휘와 간단한 문장구조의 습득이 빠르게 이루어지는 언어발달의 민감기에 속하고 언어능력측정에서도 3 개월에서 6 개월까지 단위 로 구분 할 수 있다고 하였다. 본 연구에서도 연 구대상의 영아들의 월령에 따른 인원수를 고려하 여 4 개월 단위로 나누었다.

\section{4) 사회 · 정서발달 검사도구}

영아의 사회 - 정서발달을 측정하기 위하여 사 용된 검사지는 오수경(2009)의 연구에서 사용한 것을 재사용 하였다. 영아의 사회 - 정서발달은 '교사에의 비의존성', '내적통제', ‘또래와의 상호 작용', ‘유치원에서의 안정감’, ‘성취동기', ‘호기 심' 의 6개 하위 영역으로 구성되어 있으며, 각 요소별로 9문항씩 총 54문항이다.

\section{3. 연구절차}

본 연구는 2010년 7월 26부터 2010년 10월 23 일까지 12 주간에 걸쳐 예비연구, 사전검사 및 프 로그램 실시, 사후검사로 진행되었다.

\section{1) 예비연구}

(1) 예비검사

본 연구를 실시하기에 앞서 영아의 언어발달 및 사회 - 정서발달 검사도구의 적절성과 타당성, 실험처치 과정 및 처치 시간에 대하여 알아보고 문제점을 보완하기 위해 실시하였다. 그 결과, 검 사도구가 적절하다고 판정되어 검사도구로 확정 하였다.

(2) 예비실험

프로그램의 적절성을 알아보기 위한 예비연구 로 2010년 7월 26일부터 8월6일(2주)까지 인근에 위치한 공립U어린이집 만 2 세반 영아 14 명을 대 상으로 실시하였다. 그림책읽기 후속 활동 중 6 회기 활동을 실시한 결과, 활동 수준이 만2세 영 
아들에 적합하다고 판단되었으며, 예비연구 결과 에 따라 본 프로그램을 실시하였다.

\section{2) 연구 보조자 교육}

본 연구에서는 실험집단의 교사인 본 연구자 이외에 실험집단 담당교사 1 인과 비교집단 담당 교사 2 인이 연구보조자로 참여하였다. 연구보조 자는 모두 4년제 대학의 유아교육학과를 졸업하 고 2 년 이상의 영아반 경력을 가진 교사이다. 영 아를 위한 그림책읽기 후속활동을 실험집단의 영 아에게 실시하기 전에 실험집단의 교사에게 본 연구의 목적, 이론적 근거, 영아그림책읽기 후속 활동의 실시 방법에 대한 시범과 지도방법, 지도 상의 유의점에 대한 교육과 협의를 7 월 26 일과 27 일 이틀에 걸쳐 실시하였다. 또한 비교집단의 교사에게도 본 연구의 목적, 지도방법, 지도상의 유의점에 대해 설명하였다.

\section{3) 사전 검사}

실험집단과 비교집단의 영아들의 언어발달 및 사회 - 정서발달에 대한 동질성 여부를 알아보기 위하여 사전검사를 실험처치에 들어가기 전 2010 년 8월9일부터 8월13일 까지 실시하였다.

\section{4) 프로그램 실시}

본 연구의 만 2세 영아의 그림책읽기 후속활 동은 2010년 8월16일 부터 10월16일까지 총 8주 동안 실험집단을 대상으로 실시하였다.
실험집단은 영아반 지도교사가 8주 동안 주 3 회씩 총 24회기에 걸쳐 그림책 읽기 및 그림책 읽기 후속 활동을 진행하였으며, 소요 시간은 약 20 30분이었다. 그리고 비교집단은 매주 1 권의 그림책을 주 3 회 총 24회기 동안 영아반 지도교 사가 실시하였다. 실험기간 동안 실험집단과 비 교집단의 지도교사와 프로그램에 대한 상호작용 을 실시하였다. 자세한 프로그램실시에 관한 계 획안은 표 4 와 같다.

그림책읽기 후속 활동에 대한 활동의 예는 표 5 와 같다.

\section{5) 사후검사}

그림책읽기 후속활동이 영아의 언어 및 사회 정서발달에 미치는 영향을 검증하기 위한 사후검 사는 8 주간의 실험처치가 끝난 후 사전검사와 동 일한 검사도구와 방법으로 2010년 10 월 18 일 부터 10 월 21 일 까지 실시하였다.

\section{4. 자료 분석}

그림책읽기 후속활동이 영아의 언어 및 사회· 정서발달에 미치는 영향을 알아보기 위하여 사전 검사에서는 실험집단과 비교집단의 평균과 표준 편차, 독립표본 $t$-검증을 실시하였고, 사후검사에 서는 사전검사의 일부 하위영역에서 동일성이 확 보가 되지 않아서, 실험의 정확도를 높이기 위하 여 두 집단의 사전검사 점수를 공변인으로 하고

표 4. 실험집단과 비교집단의 일과 운영

\begin{tabular}{|c|c|}
\hline 시간 & 비교집단 \\
\hline $8: 00 \sim 9: 30$ & 등원 및 자유놀이 \\
\hline $9: 30 \sim 10: 00$ & 화장실 다녀오기 및 손씻기 \\
\hline 10:00 10:30 & 오전간식 먹기 \\
\hline $10: 30 \sim 10: 50$ & 정리정돈 및 전이활동 \\
\hline $10: 50 \sim 11: 10$ & \begin{tabular}{c|c}
$\begin{array}{c}\text { 언어 및 정서관련 그림책 } \\
\text { 읽고 후속활동연계 }\end{array}$ & $\begin{array}{c}\text { 언어 및 정서 관련 } \\
\text { 그림책 읽어주기 }\end{array}$
\end{tabular} \\
\hline $11: 20 \sim 12: 30$ & 점심준비 및 점심, 이닦기 및 대소변 가리기 \\
\hline $12: 30 \sim 15: 00$ & 낮잠 준비 및 낮잠 \\
\hline $15: 00 \sim 16 ; 30$ & 낮잠깨기, 정리정돈, 화장실가기, 손씻기, 오후간식 \\
\hline 16:30 18: 00 & 실내외 자유놀이 \\
\hline 18:00 19: 30 & 조용한 놀이 귀가 준비 및 귀가 \\
\hline
\end{tabular}


표 5. 그림책읽기를 통한 영아들의 후속활동

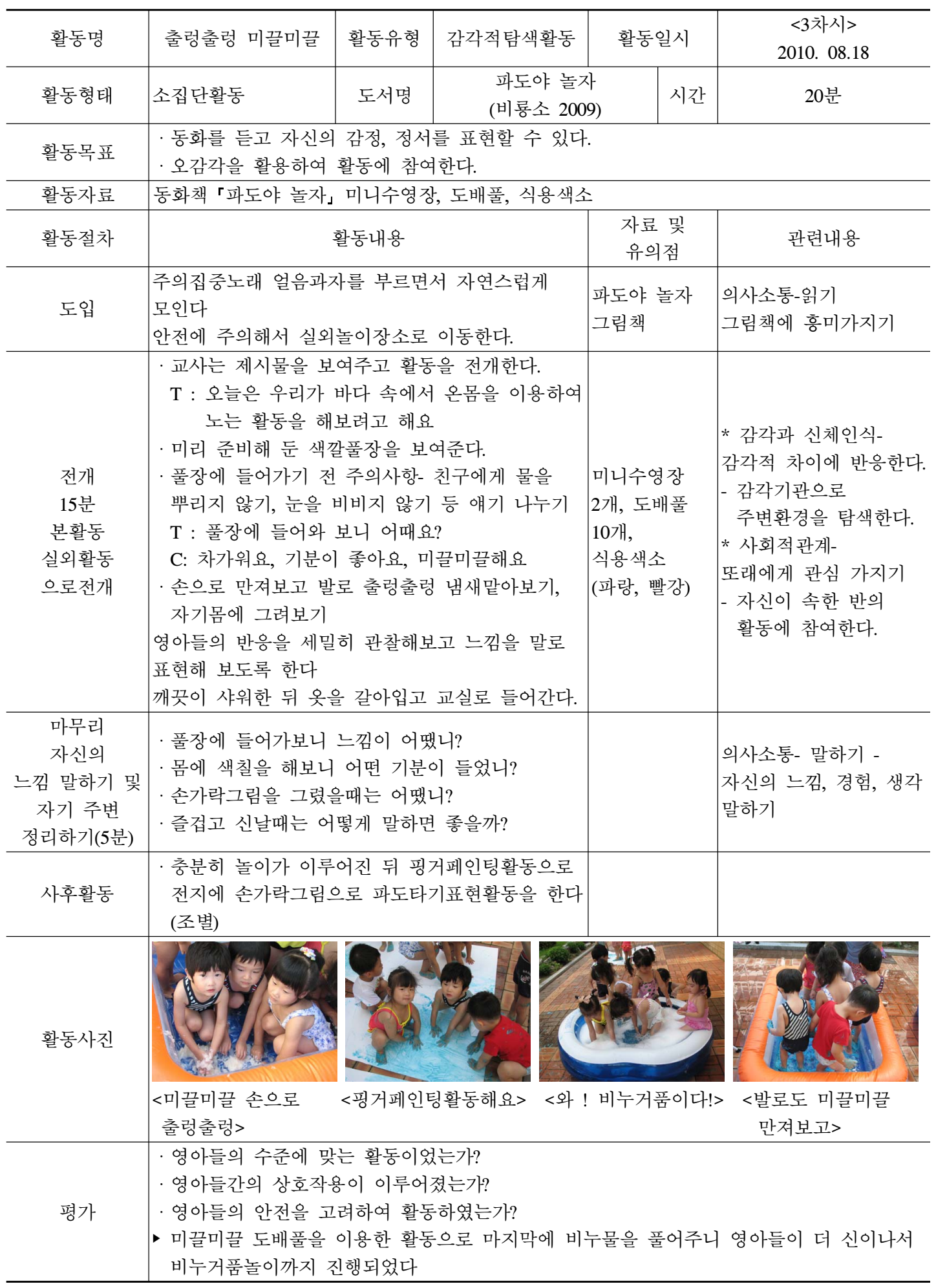


사후검사 점수를 종속변인으로 한 공분산분석 (ANCOVA)을 실시하였다. 모든 자료는 PASW 18.0 을 이용하여 분석하였다.

\section{III. 결과 및 해석}

\section{1. 그림책읽기 후속활동이 영아의 언어발달 에 미치는 영향}

\section{1) 영아 언어발달 사전 검사}

그림책읽기 후속활동을 하기 전 집단의 동질 성을 확인하기 위해 실험집단과 비교집단을 대상 으로 사전 언어발달 검사를 실시한 결과 표 6과 같다.

표 6. 언어발달에 대한 사전검사의 독립표본 $t$-검증 결과

$(\mathrm{N}=27)$

\begin{tabular}{|c|c|c|c|c|c|}
\hline 종속변수 & 집단 & 사례수 & 평균 & 표준편차 & $\mathrm{t}$ \\
\hline \multirow{2}{*}{ 표현언어 } & 비교집단 & 13 & 0.69 & 0.22 & \multirow{2}{*}{1.52} \\
\hline & 실험집단 & 14 & 0.58 & 0.18 & \\
\hline \multirow{2}{*}{ 수용언어 } & 비교집단 & 13 & 0.75 & 0.18 & \multirow{2}{*}{$2.46^{*}$} \\
\hline & 실험집단 & 14 & 0.62 & 0.08 & \\
\hline \multirow{2}{*}{ 언어발달 } & 비교집단 & 13 & 0.72 & 0.15 & \multirow{2}{*}{$2.44^{*}$} \\
\hline & 실험집단 & 14 & 0.60 & 0.11 & \\
\hline
\end{tabular}

${ }^{*} \mathrm{p}<.05$

표 6에서 제시된 바와 같이 그림책읽기 후속 활동을 실시한 영아들과 실시하지 않은 영아들의 동질성을 알아본 결과 '표현 언어' 에서는 두 집 단 간의 동질성이 확인되었으나, ‘수용언어'와 '언어발달'에서 통계적으로 유의미한 차이가 있 는 것으로 나타났다.

\section{2) 영아 언어발달 사후 검사}

영아 언어발달 사전 검사에서 $p<.05$ 의 수준에 서 유의미한 차이가 있는 것으로 나타났다. 따라 서 실험집단과 비교집단이 동질적이지 않으므로 사전 언어발달 검사 점수를 공변인으로 통제하여 언어발달 검사 총점에 대해 공분산 분석을 실시 한 결과가 표 7 과 표 8 에 제시되어 있다.
표 7. 사전, 사후 언어발달 검사와 조정된 사후 언 어발달 검사의 평균과 표준편차

$(\mathrm{N}=27)$

\begin{tabular}{|c|c|c|c|c|}
\hline \multirow{2}{*}{ 집단구분 } & $T$ & $\begin{array}{c}\text { 사전 } \\
\text { 언어발달 }\end{array}$ & $\begin{array}{c}\text { 사후 } \\
\text { 언어발달 }\end{array}$ & $\begin{array}{c}\text { 조정된 사후 } \\
\text { 언어발달 }\end{array}$ \\
\hline & 수 & $\begin{array}{c}\text { 평균 } \\
\text { (표준편차) }\end{array}$ & $\begin{array}{c}\text { 평균 } \\
\text { (표준편차) }\end{array}$ & $\begin{array}{c}\text { 평균 } \\
\text { (표준편차) }\end{array}$ \\
\hline 비교> & 13 & $0.72(0.15)$ & $0.74(0.18)$ & $0.70(0.03)$ \\
\hline 실험집단 & 14 & $0.60(0.11)$ & $0.97(0.08)$ & $1.01(0.03)$ \\
\hline
\end{tabular}

표 7에 제시된 바와 같이 사전 언어발달 검사 점수는 비교집 단 $(M=0.72, S D=0.15)$ 이 실험집단 $(M=0.60, S D=0.11)$ 에 비해 높았으며, 그림책읽기 후속활동을 실시한 이후에 다시 측정한 사후 언 어발달 검사 점수에서는 실험집단 $(M=0.97, S D=$ $0.08)$ 이 비교집단 $(M=0.74, S D=0.18)$ 보다 높은 언 어발달 점수를 받은 것으로 나타났다. 사전검사 점수에서 집단 간에 유의미한 차이가 있는 것으 로 나타났으므로 공분산 분석을 실시하여 두 집 단의 사전검사 점수를 이용해 조정 평균을 산출 한 결과, 실험집단의 언어발달 점수 $(M=1.01, S D=$ $0.03)$ 와 비교집단의 언어발달 점수 $(M=0.70, S D=$ 0.03 )간의 차이가 더 커졌음을 알 수 있다.

표 8에서 제시된 바와 같이 사전 언어발달 검 사 점수를 공변인으로 통제한 후 사후 언어발달 검사 총점에 대해 분산분석을 실시한 결과, 사후 언어발달 검사에서 $F=43.247$ 로 그림책읽기 후속 활동의 실행에 따른 실험집단과 비교집단의 사후 언어발달 검사 총점에서 유의미한 차이가 있는 것으로 나타났다.

언어발달의 하위영역으로 표현언어와 수용언 어가 있으며 수용언어 점수에서 실험집단과 비교 집단간 유의미한 차이가 있었다. 그림책읽기 후

표 8. 언어발달검사 총점 공분산분석

\begin{tabular}{lcccc}
\hline \multicolumn{1}{c}{ 분산원 } & 제곱합 & 자유도 & 제곱평균 & $\mathrm{F}$ \\
\hline 공분산 & 0.20 & 1 & 0.20 & $15.925^{* * *}$ \\
사후언어발달 & 0.54 & 1 & 0.54 & $43.247 * * *$ \\
잔차 & 0.30 & 24.00 & 0.01 & \\
\hline 합계 & 0.85 & 26 & & \\
****< 001 & & & &
\end{tabular}


속활동이 영아의 언어발달에 미치는 영향을 실험 의 정확도를 높이기 위하여 사전검사에서 각 하 위영역의 사전검사 점수를 공변인으로 두고 사후 검사를 종속변인으로 두어 공분산분석을 실시한 결과는 표 9 와 같다.

표 9. 언어발달 하위영역에 대한 공분산분석

$(\mathrm{N}=27)$

\begin{tabular}{lcccc}
\hline 분산원 & 제곱합 & 자유도 & 평균제곱 & $\mathrm{F}$ \\
\hline (공분산) & 0.04 & 1 & 0.04 & 4.093 \\
표현언어 & 0.30 & 1 & 0.30 & $27.209^{* * *}$ \\
잔차 & 0.26 & 24.00 & 0.01 & \\
\hline (공분산) & 0.23 & 1 & 0.23 & $6.391^{*}$ \\
수용언어 & 0.69 & 1 & 0.69 & $19.304^{* * *}$ \\
잔차 & 0.86 & 24.00 & 0.04 & \\
\hline
\end{tabular}

${ }^{*} \mathrm{p}<.05, * * * \mathrm{p}<.001$

표 9에서 제시된 바와 같이 언어발달의 하위 영역으로 표현언어, 수용언어가 있으며, 각 하위 영역의 사전검사 점수를 공변인으로 두고 사후검 사를 종속변인으로 두어 공분산분석을 실시한 결 과, 표현언어 $(\mathrm{F}=27.209, \mathrm{p}<.001)$ 와 수용언어 $(\mathrm{F}=$ $19.304, \mathrm{p}<.001)$ 에서 실험집단과 비교집단의 두 집단 간에 통계적으로 유의미한 차이가 나타났 다. 이러한 결과는 그림책읽기 후속활동이 단순 히 그림책읽기 활동보다 영아의 언어발달을 향상 시키는데 긍정적인 영향을 미쳤음을 의미한다.

\section{2. 그림책 읽기 후속 활동이 영아의 사회 · 정서발달에 미치는 영향}

그림책읽기 후속활동을 하기 전 집단의 동질 성을 확인하기 위해 실험집단과 비교집단을 대상 으로 사전 사회-정서발달 검사를 실시한 결과 표 10 과 같다.

\section{1) 영아 사회 · 정서발달 사전검사}

표 10에서 제시된 바와 같이 그림책읽기 후속 활동을 실시한 영아들과 실시하지 않은 영아들의 동질성을 알아본 결과 '내적통제', '또래와의 상 호작용', ‘호기심'에서는 두 집단간의 동질성이
표 10. 사회 정서발달에 대한 사전검사의 독립표 본 $t$-검증 결과

\begin{tabular}{|c|c|c|c|c|c|}
\hline & & & & & $(\mathrm{N}=27)$ \\
\hline 종속변수 & 집단 & 사례수 & 평균 & 표준편차 & $\mathrm{t}$ \\
\hline 교사에의 & 비교집단 & 13 & 3.26 & 0.56 & $267 *$ \\
\hline 비의존성 & 실험집단 & 14 & 2.64 & 0.63 & $2.6 /^{x}$ \\
\hline 개저토제 & 비교집단 & 13 & 4.14 & 0.69 & \\
\hline & 실험집단 & 14 & 4.02 & 0.80 & 0.42 \\
\hline 또래와의 & 비교집단 & 13 & 3.38 & 0.51 & \\
\hline 상호작용 & 실험집단 & 14 & 3.30 & 0.55 & 0.41 \\
\hline & 비교집단 & 13 & 4.02 & 0.43 & \\
\hline 인 & 실험집단 & 14 & 3.56 & 0.60 & 2.26 \\
\hline 서치도 기 & 비교집단 & 13 & 3.35 & 0.43 & $201+t$ \\
\hline & 실험집단 & 14 & 2.89 & 0.42 & $2.84^{* \pi}$ \\
\hline 흥 기시 & 비교집단 & 13 & 3.30 & 0.60 & 151 \\
\hline & 실험집단 & 14 & 2.98 & 0.52 & 1.51 \\
\hline 사회정서 & 비교집단 & 13 & 3.57 & 0.27 & \\
\hline 발달 & 실험집단 & 14 & 3.23 & 0.31 & $3.04 * *$ \\
\hline
\end{tabular}

확인되었으나, '교사에의 비의존성', '안정감', ‘성 취동기', ‘사회·정서총점'에서 통계적으로 유의 미한 차이가 있는 것으로 나타났다.

\section{2) 영아 사회 - 정서발달 사후검사}

영아 사회·정서발달 사전 검사에서 $p<.01$ 의 수준에서 유의미한 차이가 있는 것으로 나타났 다. 따라서 실험집단과 비교집단이 동질적이지 않으므로 사전 사회-정서발달 검사 점수를 공 변인으로 통제하여 사회·정서발달 검사 총점에 대해 공분산 분석을 실시한 결과가 표 11 과 표 12에 제시되어 있다.

표 11. 사전, 사후 사회 - 정서 발달 검사와 조정된 사 후 사회·정서발달 검사의 평균과 표준편차

\begin{tabular}{|c|c|c|c|c|}
\hline & & & & $(N=$ \\
\hline & & 사전 & 사후 & 조정된 \\
\hline & & 사회.정서 & 사회.정서 & 사회정서 \\
\hline 집 단구분 & 사례수 & 발달 & 발달 & 발달 \\
\hline & & 평균 & 평균 & 평균 \\
\hline & & (표준편차) & (표준편차) & (표준편차) \\
\hline 비교집단 & 13 & $3.57(0.27)$ & $3.74(0.29)$ & $3.65(0.07)$ \\
\hline 실험집단 & 14 & $3.23(0.31)$ & $3.96(0.27)$ & $4.04(0.07)$ \\
\hline
\end{tabular}


표 11에서 제시된 바와 같이 사전 사회 - 정서 발달 검사 점수는 비교집단 $(M=3.57, S D=0.27)$ 이 실험집단 $(M=3.23, S D=0.31)$ 에 비해 높았으며, 그 림책읽기 후속활동을 실시한 이후에 다시 측정한 사후 사회 - 정서발달 검사 점수에서는 실험집단 $(M=3.96, S D=0.31)$ 이 비교집단 $(M=3.74, S D=0.29)$ 보다 높은 사회 - 정서발달 점수를 받은 것으로 나타났다. 사전검사 점수에서 집단 간에 유의미 한 차이가 있는 것으로 나타났으므로 공분산 분 석을 실시하여 두 집단의 사전검사 점수를 이용 해 조정 평균을 산출한 결과, 실험집단의 사회·정 서발달 점수 $(M=4.04, S D=0.07)$ 와 비교집단의 사 회 - 정서발달 점수 $(M=3.65, S D=0.07)$ 간의 차이가 더 커졌음을 알 수 있다.

표 12. 사회 · 정서발달 검사 총점 공분산분석

\begin{tabular}{lcccc}
\hline 분산원 & 제곱합 & 자유도 & 제곱평균 & $\mathrm{F}$ \\
\hline 공분산 & 0.54 & 1 & 0.54 & $9.467^{* *}$ \\
$\begin{array}{l}\text { 사후사회 } \\
\text { 정서발달 }\end{array}$ & 0.77 & 1 & 0.77 & $13.521^{* *}$ \\
잔차 & 1.37 & 24.00 & 0.06 & \\
\hline 합계 & 2.25 & 26 & & \\
\hline$* * * \mathrm{p}<.001$ & & & &
\end{tabular}

표 12에서 제시된 바와 같이 사전 사회 - 정서 발달 검사 점수를 공변인으로 통제한 후 사후 사 회 - 정서발달 검사 총점에 대해 분산분석을 실 시한 결과, 사후 사회 - 정서발달 검사에서 $F=$ 13.521로 그림책읽기 후속활동의 실행에 따른 실 험집단과 비교집단의 사후 사회 - 정서발달 검사 총점에서 유의미한 차이가 있는 것으로 나타났다.

사회 - 정서발달 검사의 하위영역으로 교사에 의 비의존성, 내적통제, 또래와의 상호작용, 유치 원에서의 안정감, 성취동기, 호기심이 있으며 사 전검사의 일부 하위영역에서 집단 간 유의미한 차이가 있었다. 따라서 그림책읽기 활동이 영아 의 사회 - 정서발달에 미치는 영향을 실험의 정 확도를 높이기 위하여 두 집단의 사전점수인 '교 사에의 비의존성', '내적통제', '또래와의 상호작 용', ‘유치원에서의 안정감', ‘성취동기', ‘호기심',
‘사회정서총점'을 공변인 으로 하고, 사후검사 점 수를 종속변인으로 한 공분산분석(ANCOVA)으 로 실시한 결과는 표 13 과 같다.

표 13. 사회 정서발달 하위영역에 대한 공분산분석

$(\mathrm{N}=27)$

\begin{tabular}{|c|c|c|c|c|}
\hline 분산원 & 제곱합 & 자유도 & $\begin{array}{l}\text { 평균 } \\
\text { 제곱 }\end{array}$ & $\mathrm{F}$ \\
\hline (공분산) & 0.93 & 1 & 0.93 & $4.317^{*}$ \\
\hline 교사에의 비의존성 & 0.16 & 1 & 0.16 & 0.747 \\
\hline 잔차 & 5.19 & 24.00 & 0.22 & \\
\hline (공분산) & 1.37 & 1 & 1.37 & $9.471^{* *}$ \\
\hline 내적통제 & 1.77 & 1 & 1.77 & $12.209 * *$ \\
\hline 잔차 & 3.48 & 24.00 & 0.14 & \\
\hline (공분산) & 3.58 & 1 & 3.58 & $23.889 * * *$ \\
\hline 또래와의 상호작용 & 3.83 & 1 & 3.83 & $25.525^{* * *}$ \\
\hline 잔차 & 3.60 & 24.00 & 0.15 & \\
\hline (공분산) & 1.91 & 1 & 1.91 & $13.554 * *$ \\
\hline 유치원에서의 안정감 & 0.28 & 1 & 0.28 & 1.989 \\
\hline 잔차 & 3.39 & 24.00 & 0.14 & \\
\hline (공분산) & 0.89 & 1 & 0.89 & $5.926^{*}$ \\
\hline 성취동기 & 1.05 & 1 & 1.05 & $6.962 *$ \\
\hline 잔차 & 3.61 & 24.00 & 0.15 & \\
\hline (공분산) & 1.90 & 1 & 1.90 & $10.526^{* *}$ \\
\hline 호기심 & 0.10 & 1 & 0.10 & 0.528 \\
\hline 잔차 & 4.32 & 24.00 & 0.18 & \\
\hline
\end{tabular}

$* \mathrm{p}<.05, * \mathrm{p}<.01, * * * \mathrm{p}<.001$

표 13을 살펴보면, 사회 - 정서발달의 하위영역 으로 교사에의 비의존성, 내적통제, 또래와의 상 호작용, 유치원에서의 안정감, 성취동기, 호기심 이 있으며, 각 하위영역의 사전검사 점수를 공변 인으로 두고 사후검사를 종속변인으로 두어 공분 산분석을 실시한 결과, 교사에의 비의존성, 안정 감, 호기심에서는 통계적으로 유의미한 차이가 나타나지 않았고, '내적통제 $(\mathrm{F}=12.209, \mathrm{p}<.01)$ ', '또래와의 상호작용 $(\mathrm{F}=25.525, \mathrm{p}<.001)$ ', '성취동기 $(\mathrm{F}=6.962, \mathrm{p}<.05)^{\prime}$ 에서 실험집단과 비교집단의 두 집단 간에 통계적으로 유의미한 차이가 나타났 다. 이러한 결과는 그림책읽기 후속활동이 단순 히 그림책읽기 활동보다 영아의 사회 - 정서발달 
을 향상시키는데 부분적으로 긍정적인 영향을 미 쳤음을 의미한다.

\section{IV. 논의 및 고찰}

본 연구의 연구 문제에 따른 결과를 제시하고 논의점을 살펴보면 다음과 같다.

첫째, 그림책읽기 후속활동이 영아의 언어발달 에 긍정적인 영향을 미친 것으로 나타났다. 언어 발달의 하위영역인 수용언어와 표현언어 에서도 공분산 분석을 실시한 결과 표현언어 $(\mathrm{F}=27.209$, $\mathrm{p}<.001)$ 와 수용언어 $(\mathrm{F}=19.304, \mathrm{p}<.001)$ 에서 실험집 단과 비교집단의 두 집단 간에 통계적으로 유의 미한 차이가 나타났다. 이러한 결과는 이 시기 영아는 언어발달의 결정적시기이며 언어가 폭발 적으로 일어나는 시기라 할 수 있기에 어떠한 언 어적 환경을 조성해 주고 영아의 언어적 반응에 성인이 어떻게 반응하느냐에 따라서 영아기 언어 능력이 다르게 영향 받을 수 있다는 것을 알 수 있었다.

그림책을 통해 영아들은 많은 언어자료에 접 하게 되고 어휘, 문법, 의사소통기술, 쓰여진 상 징과 이야기 구조들에 관한 정보 등을 접하게 된 다. Whitehurst와 Lonigan(1998)이 가정과 어린이 집에서 날마다 독서를 한 2,3 세 아동들은 그렇 지 못한 아동들에 비해 언어기술면에서 대단히 진전되었다고 한 것과 같이 그림책을 활용한 언 어활동은 실험집단과 비교집단 모두에게 언어능 력의 향상을 보였다. 하지만 그림책을 단순히 교 사가 들려주는 것에 그치지 않고 질문하고, 어휘 와 문장을 따라해 보고 각자의 역할을 정해서 극 놀이 활동을 하고 신체활동, 감각활동, 조형활동, 음률활동 등을 해 본 결과에 대한 언어 능력은 두 집단간에 유의한 차이가 나타났다. 이러한 사 실은 그림책을 활용한 극 놀이 활동이 영아의 언 어발달에 영향을 미친다는 정경희(2010)의 연구 결과와 교사의 그림책읽기 상호작용 유형에 따라 영아의 언어발달에 영향을 미친다는 남규(2009) 의 연구결과, 그림책을 활용한 통합적 언어활동 이 영아의 언어능력향상에 영향을 미친다는 조성 원(2008)의 연구결과, 영아언어발달을 위한 상호
작용적 그림책읽기모형의 적용결과 언어발달에 효과가 있었다는 김정아(2006)의 연구결과, 그림 책을 활용한 언어활동 프로그램이 영아의 어휘력 과 의사소통 능력향상에 영향을 미친다는 안주희 (2005)의 연구결과, 영아의 그림책 관련표상활동 의 구성 및 적용결과 영아의 언어발달에 효과가 있었다는 오애순(2004)의 연구결과와 일치한다.

그림책을 읽고 후속활동을 경험한 실험집단과 그림책읽기활동만 경험한 비교집단 간에는 언어 능력 중 표현 언어 향상에서 유의미한 차이가 있 었다. 실험집단의 점수가 비교집단의 점수보다 높은 것으로 나타난 것은 비교집단의 영아들은 수동적으로 동화를 듣고 이해하는데 그치지만 실 험집단의 영아들은 동화를 듣고 어휘와 문장을 따라해 보고 후속활동으로 연계하여 대소근육활 동(게임), 감각적 탐색활동, 창의적 활동(동극, 조 형, 음률)등 다양한 활동으로 전개하였다. 후속활 동 과정에서 영아에게 여러 가지 상황에서 표현 할 수 있는 언어의 기회를 다양하게 많이 제공하 였으며 그림책과 관련된 활동 등을 전개함으로써 그림책을 더 친근하게 받아들이고 능동적으로 활 동에 참여하여 영아들이 충분히 오감을 활용, 신 체를 움직여 다양한 언어표현이 늘어난 결과 실 험집단의 영아들의 표현 언어능력이 보다 향상된 것으로 여겨진다.

그림책을 읽고 후속활동을 경험한 실험집단과 그림책읽기활동만 경험한 비교집단 간에는 언어 능력 중 수용언어 향상에도 유의미한 차이가 있 었다. 이와 같은 결과는 그림책을 읽고 후속활동 을 전개한 실험집단의 영아들이 수용언어에 긍정 적인 영향을 미친다는 것을 의미한다. 영아가 이 야기 전개 상황에서 말이나 글로만 표현하는 경 우에는 쉽게 그 내용을 기억하기는 어렵지만 동 극으로 경험했을 때 줄거리를 더 잘 기억하고 교 사나 또래의 말이나 행동에 관심을 가지며 동화 와 관련된 게임을 하면서 교사나 또래의 말을 듣 고 그 뜻을 이해하며, 감각놀이를 통해 온 몸으 로 체험한 결과 실험집단의 영아들의 수용언어능 력이 보다 향상된 것으로 여겨진다.

둘째, 그림책읽기 후속활동을 실시한 실험집단 과 그림책읽기활동만 한 비교집단에 대한 사후검 
사 결과 실험집단 영아의 사회·정서발달 점수 가 비교집단의 영아에 비해 통계적으로 유의한 차이가 있는 것으로 나타났다. 사회·정서발달의 하위요소별 결과를 살펴보면 '교사에의 비의존 성', '안정감', '호기심'을 제외하고 '내적통제', '또래와의 상호작용', '성취동기' 에서 유의한 차 이가 있는 것으로 나타났다. 이러한 결과는 그림 책읽기 후속활동프로그램이 유아의 정서능력에 영향을 미친다는 양정숙(2006)의 연구결과, 그림 책에 기초한 감성교육 프로그램이 유아의 감성지 능에 영향을 미친다는 강은애·현은자(2005)의 연구결과, 그림책관련활동이 유아의 정서조절에 영향을 미친다는 박성희(2003)의 연구결과, 그림 책을 통한 활동이 유아의 정서기능발달에 영향을 미친다는 김소연(2002)의 연구결과, 그림동화책 읽어주기와 토의가 유아의 사회 - 정서적 발달에 영향을 미친다는 신정숙(2002)의 연구결과와 일 치한다.

영아는 자신의 감정을 표현하려는 요구와 다 른 사람과 의사소통하려는 요구를 가지고 있으므 로 그림책읽기 후속활동은 자신의 감정을 표현하 고 조절시키도록 돕는다. 그림책읽기 후속활동을 통해 타인의 정서를 느껴보고 자신의 감정이나 정서를 언어로 표현해보았다. 또한 후속활동을 통해서 친구와 극놀이 하기, 친구와 신체활동에 참여해 봄으로써 또래와 관계를 맺는 사회적 기 술을 갖게 되고 다양한 재료를 통한 탐색활동 등 으로 영아들의 사회·정서발달이 증진된 것으로 볼 수 있다.

사회 - 정서발달의 하위요소별 결과를 살펴보 면 사회 - 정서발달의 하위영역인 '교사에의 비의 존성', ‘안정감,' ‘호기심'은 통계적으로 유의한 차이가 없었다. 영아의 발달적 특성을 보면 영아 는 그들의 욕구충족과 만족을 얻기 위하여 전적 으로 성인에게 의존한다. 영아기는 완전한 성인 의 보호를 필요로 하는 시기이다. 쉴새없이 적극 적으로 환경에 대한 탐색을 시도하지만 성인이 돌보아 주고 제공해 주는 범위 내에서 활동한다 는 점에서 어느 시기보다도 성인의 역할이 중요 하다고 할 수 있다. 이러한 영아들의 발달특성 때문에 “교사에의 비의존성"은 사전, 사후 유의
미한 차이가 나지 않는 것으로 사료된다.

‘안정감'은 영아들의 내면적인 심리상태를 표 현하는 것으로서 어린이집에 입학하는 2 세 영아 들은 ‘어린이집에서의 안정감'이 어느 정도 형성 되어 있다고 볼 수 있다. 연구가 진행되는 시기 가 영아들이 어린이집에 적응되어 기관과 교사와 의 안정감이 형성된 시기이기 때문에 '어린이집 에서의 안정감' 에서는 유의한 차이가 나지 않는 것으로 해석된다.

‘호기심' 을 살펴보면 영아들은 자기조절력과 통제력은 아직도 미숙하면서 잠시도 쉬지 않고 만지작거리고 움직이고 이야기하는 지칠 줄 모르 는 왕성한 호기심을 갖고 있는, 한없이 재미있고 호기심 있게 이 세상을 탐색하고 배우는 존재들 이다. 이러한 영아의 발달특성으로 인해 호기심 에서는 실험집단과 비교집단 간의 유의한 차이가 나지 않은 것으로 여겨진다.

또한 그림책읽기 후속활동이 잘 진행된 이유 를 보면 초기에는 영아들이 활동에 대해 익숙하 지 않았지만 활동이 점차 실시되어감에 따라 영 아들이 점점 신체를 움직여 감각적 탐색활동을 함으로써 자신의 감정을 친구들과 자연스럽게 표 현해 보고 여러 가지 신체활동을 통해 또래와 어 울려 놀이를 하게 되어 사회 - 정서발달에 긍정적 인 영향을 미친 것으로 생각된다. 이는 또래와 교사와의 상호작용을 통하여 친밀감을 형성하게 되어 보육기관에 적응해 나가고 또래와의 상호작 용이 향상되었음을 유추할 수 있다. 또한 초기에 는 동화듣기, 창의적 활동(극놀이)이나 순서를 기 다려야하는 부분에서 자기 자신을 억제하지 못하 는 행동들이 보였다. 동화를 듣다가 일어나고 극 놀이에서 순서를 무시하는 등의 행동을 보였지만 활동이 진행됨에 따라 자기 자신을 억제하면서 게임에서 차례지키기, 극놀이에서 자기역할을 기 다렸다 표현해보는 등 프로그램 후기에는 대체로 활동이 원만하게 이루어진 것으로 보아 영아들의 자아통제력이 점차 발달하였음을 유추할 수 있 다. 또한 프로그램 초기에는 그림책읽기 후속활 동에 영아들이 적극적으로 참여하는 것을 어려워 하였으나 회기가 진행될수록 창의적 활동이나 게 임 활동, 감각적 탐색 활동 등을 통해 자기 자신 
에 대한 자긍심과 긍정적 태도 등을 보이며 인내 심을 가지고 활동을 마무리하는 열성도 보였다. 이런 결과를 볼 때 그림책읽기 후속활동은 영아 들의 성취감 형성에도 긍정적인 영향을 미친 것 으로 볼 수 있다. 이상의 결과들을 볼 때 그림책 읽기 후속활동을 실시한 영아들이 그림책읽기만 실시한 영아들에 비해 사회-정서발달이 증진되 었음을 알 수 있다.

이상의 내용을 종합해 볼 때, 그림책읽기 후속 활동은 영아에게 친근한 매체인 그림책을 읽고 관련 다양한 활동을 영아들에게 경험함으로써 영 아들의 언어능력이 향상되고 사회·정서발달에 있어서도 긍정적인 영향을 미침을 알 수 있었다. 더 나아가 다른 영역의 발달을 도울 수 있는 원 동력이 되기 때문에 전반적인 영아발달을 돕는 의미에서 계획적이고 체계적인 발달에 적합한 그 림책읽기 후속활동을 지속적으로 실시해 볼 가치 가 있다고 여겨진다. 따라서 영아보육현장에서 영아를 위한 다양한 그림책읽기 후속활동프로그 램을 제공한다면 영아의 언어 및 사회-정서발 달을 효과적으로 증진시키는데 도움을 줄 수 있 을 것으로 본다.

이와 같은 결과를 토대로 후속 연구를 위해 다음과 같이 제언하고자 한다.

첫째, 본 연구는 그림책읽기 후속활동의 효과 를 단기간의 결과에 기초하였으나, 추후 연구는 그림책읽기 후속활동의 효과에 관한 연구를 한 학기 또는 일년으로 지속하여 보다 장기간에 걸 친 효과에 대한 연구가 이루어져야 할 것이다.

둘째, 본 연구는 그림책읽기 후속활동을 어린 이집 현장에서 적용하고 검증하였으나 교사와 함 께 부모가 영아에게 의미 있는 사회적 중재자임 을 감안할 때 어린이집에서 실시되고 있는 실험 에 활용되는 동화의 목록과 활동의 내용을 부모 에게 안내함으로써 얻어지는 연계교육의 효과를 검증하는 연구가 필요할 것이다.

셋째, 본 연구는 그림책읽기 후속활동을 경험하 면서 영아가 개별적으로 어떤 변화를 보이는지에 대한 부분이 누락되었다. 따라서 후속 연구에서는 정서교육 활동 경험에 따라 영아의 개별적인 변화 를 질적 연구의 방법으로 탐구할 필요가 있다.

\section{참고문헌}

강은애 - 현은자(2005) 그림책에 기초한 감성교육 프로그램이 유아의 감성지능에 미치는 영향. 성균관대학교 생활과학연구 8, 211-234

김소연(2002) 그림책을 통한 활동이 유아의 정서지 능발달에 미치는 영향. 경성대학교 교육대학원 석사학위청구논문.

김세희(2000) 유아 문학 교육. 서울: 양서원.

김영태(2003) 영유아 언어발달 검사. 서울: 특수교육. 김영태 - 성태제 - 이윤경(2003) 취학 전 아동의 수 용언어 및 표현언어 발달척도 서울: 서울장애 인 복지관.

김정아(2006) 영아언어발달을 위한 상호작용적 그 림책읽기모형의 적용 및 효과. 전남대학교 교 육대학원 석사학위청구논문.

김현희 - 박상희 (1999) 유아 문학 교육. 서울: 학지사.

남 규(2009) 교사의 그림책읽기 상호작용 유형에 따른 영아의 언어발달 비교. 건국대학교 대학 원 박사학위청구논문.

박성희(2003) 그림책관련활동이 유아의 정서조절에 미치는 영향. 중앙대학교 교육대학원 석사학위 논문.

신정숙(2002) 그림동화책 읽어주기와 토의가 유아 의 사회·정서적 발달에 미치는 효과. 카톨릭 대학교 교육대학원 석사학위논문.

안주희(2005) 그림책을 활용한 언어활동 프로그램 이 영아의 어휘력과 의사소통능력 향상에 미치 는 영향. 숭실대학교 교육대학원 석사학위논문.

양정숙(2006) 그림책읽기후속활동프로그램이 유아의 정서능력에 미치는 영향. 조선대학교 대학원 석사학위논문.

오수경(2009) 자연친화 체험활동이 영아의 지각운 동능력 및 사회정서발달에 미치는 영향. 성신 여자대학교 교육대학원 석사학위논문

오애순(2004) 영아의 언어 발달을 위한 그림책 관 련 표상활동의 구성 및 적용 효과. 덕성여자대 학교 대학원 박사학위논문.

오진희(2000) 그림책 읽기에서 나타난 교사의 언어 적 유형에 따른 영아의 반응 분석. 덕성여자대 학교 석사학위논문.

이경우 · 장영희 - 이차숙 - 노영희 · 현은자(1997) 유 아에게 적절한 그림책. 서울: 양서원.

이상금(1998) 그림책을 보고 크는 아이들. 서울: 사 계절.

이송은(2006) 2 세 영아의 책에 대한 의미 탐색. 중 앙대학교 교육대학원 박사학위논문.

장영희(2005) 영아교육과정. 서울: 양서원.

정경희(2010) 그림책을 활용한 극놀이활동이 영아 의 언어발달에 미치는 영향. 경성대학교 교육 대학원 석사학위논문.

조성원(2008) 그림책을 활용한 통합적 언어활동이 영아의 언어능력향상에 미치는 영향. 숭실대학 교 교육대학원 석사학위논문. 
최석란(2007) 영아의 사회정서발달과 보육교사의 역 할. 사회과학논총 $14,97-116$.

한은숙(2005) 영유아 발달과 교육. 서울: 정민사.

Bridges $\mathrm{KMB}(1930)$ Genetic theory of emotions. Journal of Genetic Psychology 37, 514-527.
Mayer JD, Salovey $\mathrm{P}(1997)$ What is emotional intelligence? In P. Salovey \& D. Sluyter (Eds). Emotional Development and Emotional Intelligence: Implications for Educators (pp. 3-31). New York: Basic Books.

Whitehurst GJ, Lonigan CJ(1998) Child development and emergent literacy. Child Development 69(3), 848-872. 